\title{
Does Cattle Grazing Affect Ant Abundance and Diversity in Temperate Grasslands?
}

\author{
Amanda C. Schmidt, ${ }^{1}$ Lauchlan H. Fraser, ${ }^{2}$ Cameron N. Carlyle, ${ }^{3}$ and Eleanor R.L. Bassett ${ }^{4}$
}

Authors are ${ }^{1}$ Research Assistant, Biological Sciences, Thompson Rivers University, Kamloops, BC V2C 5N3, Canada; ${ }^{2}$ Professor and ${ }^{4}$ MSc Student, Natural Resource Sciences, Thompson Rivers University, Kamloops, BC V2C 5N3, Canada; and ${ }^{3}$ Doctoral Student, Botany Department, University of British Columbia, Vancouver, BC V6T 1Z4, Canada.

\begin{abstract}
Half of the world's land base is grazed by domesticated livestock. Because of the important functional role of ants in grasslands, it is important to understand the effect of livestock grazing on ant abundance and diversity. The objectives of this study were to examine the effect of cattle grazing and site productivity on the abundance, species richness, and species diversity of ants in Lac du Bois Grasslands Provincial Park, British Columbia, Canada. We hypothesized that the measured ant variables would be lowest in grazed areas and at low site productivity. Pitfall trapping was conducted at four sites: two at each low and high site productivity levels. At each site an ungrazed (fenced exclosure) and grazed transect was sampled during May, July, and August of 2008. Captured ants were preserved in ethanol and identified. Eight genuses of ants were collected: Tapinoma, Camponotus, Formica, Lasius, Aphaenogaster, Myrmica, Solinopsis, and Temnotharox. The mean number of ants per pitfall was higher at high site productivity sites that were grazed $(15.10 \pm 2.96 \mathrm{SE})$ compared to high productivity sites ungrazed $(3.28 \pm 0.47 \mathrm{SE})$; grazing at low productivity reduced numbers of ants from $5.07( \pm 0.70 \mathrm{SE})$ to $2.20( \pm 0.39 \mathrm{SE})(\mathrm{F}=21.806 ; P<0.001)$. Tapinoma sessile and A. occidentalis had the greatest numbers in the pitfall traps. Species richness $(\mathrm{F}=23.330, P<0.001)$ and diversity $(\mathrm{F}=11.764, P=0.001)$ followed a similar trend. Because productivity and cattle grazing affect ant diversity and abundance, and ants impact ecosystem functioning, these factors should be considered in management of grasslands.
\end{abstract}

\section{Resumen}

La mitad de las tierras del mundo son pastoreadas por animales domésticos. Debido a la importancia práctica de las hormigas dentro de los pastizales es importante comprender el efecto del ganado en pastoreo en la diversidad y abundancia de las hormigas. Los objetivos de este estudio fueron examinar el efecto del pastoreo y la productividad del sitio en la abundancia, la riqueza, y la diversidad de especies de hormigas en los pastizales de Lac du Bois en el parque Provincial, de la Columbia Británica, en Canadá. Nuestra hipótesis fue que las variables medidas en las hormigas serían menores en áreas pastoreadas y en sitios de menor productividad. Se utilizaron trampas en cuatro sitios: dos por cada sitio de alta y baja productividad. En cada sitio, transectos en áreas sin pastoreo (excluidas) y con pastoreo fueron muestrados durante mayo, Julio y Agosto del 2008. Las hormigas capturadas fueron conservadas en etanol e identificadas. Se recolectaron 8 géneros de hormigas: Tapinoma, Camponotus, Formica, Lasius, Aphaenogaster, Myrmica, Solinopsis, and Temnotharox. El número medio de hormigas por trampa fue mayor en de alta productividad y que fueron pastoreados (15.10 $\pm 2.96 \mathrm{SE})$ comparados a los sitios de alta productividad sin pastoreo ( $3.28 \pm 0.47 \mathrm{SE}$ ); mientras que en los sitios de baja productividad se redujo el número de hormigas de $5.07( \pm 0.70 \mathrm{SE})$ a 2.20 ( $\pm 0.39 \mathrm{SE})(\mathrm{F}=21.806 ; P<0.001)$. Las hormigas Tapinoma sessile y A. occidentalis tuvieron los mayores números en las trampas. La riqueza de las especies $(\mathrm{F}=23.330, P<0.001)$ y la diversidad $(\mathrm{F}=11.764, P=0.001)$ siguió una tendencia similar. Debido a que la productividad y el pastoreo del ganando afectan la diversidad, la abundancia, y el impacto de las hormigas en el funcionamiento del ecosistema, estos factores deben considerarse en el manejo de los pastizales.

Key Words: disturbance, Formicidae, productivity, rangelands, semiarid grasslands

\section{INTRODUCTION}

Ants (Hymenoptera: Formicidae) represent $10-15 \%$ of animal biomass in the majority of terrestrial systems and are among the most dominant land organisms on Earth (Hölldobler and Wilson 1990). Ants contribute to ecosystem function in their ecological roles as pollinators (Hölldobler and Wilson 1990), predators, and prey (Raine and Kansas 1990; Bull et al. 1995; Torgerson and Bull 1995; Noyce et al. 1997); and have important roles in grasslands as soil engineers (Whitford et al.

Research was funded in part by a Natural Sciences and Engineering Research Council of Canada Discovery Grant to L. H. Fraser.

Correspondence: Lauchlan Fraser, Natural Resource Sciences, Thompson Rivers University, Kamloops, BC V2C 5N3, Canada. Email: Ifraser@tru.ca

Manuscript received 16 June 2011; manuscript accepted 15 February 2011.
1986), seed predators and foragers (Brown and Davidson 1977; Brown et al. 1979; Higgins and Lindgren 2006), and scavengers and decomposers (Hölldobler and Wilson 1990). Given the dominance and diverse functional roles of ants in ecosystems it is important to understand patterns in their distribution, abundance, and diversity.

Considering that grazing by domesticated livestock occurs on approximately half of the Earth's land surface (Havstad 2008), it is necessary to understand how the disturbance caused by grazing may affect ant communities. Consensus as to the effects of disturbance, in general, on ant communities has yet to be reached; however, it is clear that different types of disturbance (fire, agricultural, etc.) affect ant communities differently (Folgarait 1998; Anderson and Majer 2004; Hoffmann 2010). Furthermore, ant functional groups for Australia and 
North America have been classified in relation to disturbance and stress (Andersen 1995, 1997). The effect of cattle grazing, one type of disturbance in grasslands, reviewed by Folgarait (1998), found that heavy grazing generally reduces ant density and diversity, but some studies have been contradictory, showing either no effect or even positive effects of grazing to overall ant richness (Abensperg-Traun et al. 1996; Majer and Beeston 1996; Bestelmeyer and Wiens 1996, 2001).

Energy availability is generally accepted as a factor that limits diversity in natural systems (Hutchinson 1959; Connell and Orias 1964; Currie 1991; Kaspari et al. 2000). Organisms in higher trophic levels depend (either directly or indirectly) on energy from primary producers. Because a high productivity area can provide more energy to consumers than a low productivity area of the same size, the high productivity area will generally be able to support more individuals. If more individuals are present, there is a greater chance that individuals from rare species will also be present and diversity will be higher as a result (Kaspari et al. 2000). When productivity is low, energy availability can limit the abundance of consumer taxa, and rare species, represented by few individuals, are less likely to exist (Hutchinson 1959). By this reasoning, constraining density also constrains diversity (Hutchinson 1959; Connell and Orias 1964). In general, the same positive relationship exists between productivity and ant abundance and diversity (Kaspari et al. 2000).

This study examined the effects of productivity and cattle grazing on the relative numbers of ants and on species richness and species diversity of the ant community in the grasslands of Lac du Bois Grasslands Provincial Park, British Columbia, Canada. It was hypothesised that the relative number of ants and the species richness and species diversity of ants would increase with increasing productivity, and decrease with cattle grazing. To study this, pitfall trapping was conducted in areas differing in productivity level and grazing intensity at different times during the growing season of 2008. Although there are other methods available for estimating ant abundance, such as direct and intensive sampling, pitfall trapping is recommended for intersite comparisons (Romero and Jaffe 1989). However, it should be noted that because some ants in a colony follow each other's trails (Hölldobler and Wilson 1990), the chance of catching an ant of a given species may increase with every ant of that species caught.

\section{METHODS}

\section{Site Description}

Ant specimens were collected from the temperate grasslands in Lac du Bois Provincial Park and adjacent areas within the bunchgrass grasslands $2-10 \mathrm{~km}$ north of Kamloops in the southern interior of British Columbia, Canada. The region is semiarid, with annual precipitation of $279 \mathrm{~mm}, 75.5 \mathrm{~mm}$ of which is snowfall. Average annual daily temperature for the region is $8.9^{\circ} \mathrm{C}$, the warmest month is July, $21.0^{\circ} \mathrm{C}$, and the coldest is January, $-4.2^{\circ} \mathrm{C}$ (Environment Canada 2009). We selected two different grassland types associated with elevation, lower grasslands (between 400 and $600 \mathrm{~m}$ above sea level [a.s.l.]) and upper grasslands (between 800 and $1000 \mathrm{~m}$ a.s.l.). A productivity gradient correlates positively with elevation across the study area. This gradient is thought to be driven by a decrease in transpiration rate with increasing elevation, where rainfall is higher and temperature is cooler than at lower elevations (van Ryswyk et al. 1966; Carlyle et al. 2011). In 2007 , from May to September, a mean temperature of $19.3^{\circ} \mathrm{C}$ was recorded in the lower grasslands and $15.4^{\circ} \mathrm{C}$ in the upper grasslands. The mean total rainfall for the same period was $96 \mathrm{~mm}$ in the lower grasslands and $145 \mathrm{~mm}$ in the upper grasslands (C. Carlyle, unpublished data). The lower grasslands have high levels of bare ground and are dominated by Pseudoroegneria spicata (Pursh) A. Love (bluebunch wheatgrass) and the shrub Artemisia tridentata Nutt. (big sagebrush), with Poa secunda J. S. Presl (Sandberg's bluegrass) and Vulpia octiflora (Walter) Rydb. (six-week fescue) as other common species. The upper grasslands are devoid of shrubs, have very little bare ground, and are dominated by Festuca campestris L. (rough fescue); Poa pratensis L. (Kentucky bluegrass) and Juncus balticus Willd. (Baltic rush) are the next most common species. Plant live and litter biomass is approximately four times greater in upper grasslands compared to lower grasslands, and is reduced by grazing (Bassett 2009). The lower grassland soil is a brown Chernozerm with a fine sandy loam texture; the upper grassland soils are black Chernozerm (van Ryswyk et al. 1966).

Grasslands in Lac du Bois Park are grazed by cattle from April to November on a rest-and-rotation schedule at an animal unit measurement of approximately one cow per hectare. Pastures grazed in the spring one year have been rested the second year, grazed in the fall the third year, and rested the fourth year on an ongoing cycle over the past four decades. Approximately 20-yrold fenced cattle exclosures $100 \times 150 \mathrm{~m}$ exist within the park as reference sites to monitor changes in vegetation with the exclusion of cattle grazing. We selected four paired grazed and ungrazed (fenced) sites, two at lower and two at upper elevations (Table S1, available at http://dx.doi.org/10.2111/REM-D-1100100.s1), for a total of eight experimental sites.

\section{Pitfall Traps}

In July 2007, pitfall traps were placed every $10 \mathrm{~m}$ on a $90-\mathrm{m}$ transect in each grazed and exclosed areas at each site for a total of 10 traps per transect and 20 traps per site. A buffer of at least $2 \mathrm{~m}$ was maintained from fence lines. Traps were dug into the ground so that the tops were even with ground level. Each trap was made of a funnel and small cup (50-mm diameter, 30-mm depth) in a larger cup (9-mm diameter, 97-mm depth) (Brose 2003). Two holes were punched in the bottom of each large cup to create a drain for overflow from rain. Traps were covered with plywood cover boards $(30 \times 30 \times 4 \mathrm{~cm})$ to reduce capture of Staphylidae beetles, Orthopterans, and Dipterans, and were set by filling the small cup with $20 \mathrm{ml}$ each of propylene glycol and water (Grandchamp et al. 2005). In 2008, traps were set for 1 wk starting May 15, July 16, and August 21 for a total of three trapping periods. Samples were collected and stored in denatured alcohol until they were sorted and counted.

\section{Identification}

Individuals were identified to species, but when this was not possible they were identified to genus or species group. 
Table 1. List of the species captured and the locations of their capture. $L G=$ lower grasslands, $U G=$ upper grasslands. Ants were identified to species when possible; if species could not be determined they were listed under a higher taxonomic group. ${ }^{1}$

\begin{tabular}{|c|c|c|c|}
\hline Subfamily & Genus & $\begin{array}{c}\text { Species or } \\
\text { species group }\end{array}$ & $\begin{array}{l}\text { Elevation of } \\
\text { occurrence }\end{array}$ \\
\hline Dolichoderinae & Tapinoma & sessile & LG, UG \\
\hline \multirow[t]{5}{*}{ Formicinae } & Camponotus & vicinus & LG \\
\hline & Formica & Fusca species group & LG, UG \\
\hline & & $\begin{array}{c}\text { Rufa and Microgyna } \\
\text { species groups }\end{array}$ & LG, UG \\
\hline & & $\begin{array}{l}\text { Sanguinea species } \\
\text { group }\end{array}$ & $U G$ \\
\hline & Lasius & & LG, UG \\
\hline \multirow[t]{6}{*}{ Myrmicinae } & Aphaenogaster & occidentalis & LG, UG \\
\hline & Myrmica & crassirugis & LG, UG \\
\hline & & fracticornis & UG \\
\hline & Solinopsis & molesta & $L G$ \\
\hline & Temnothorax & rugatulus & $L G$ \\
\hline & & nevadensis & $L G$ \\
\hline
\end{tabular}

${ }^{1}$ The Fusca species group included F. hewitti and F. subpolita. The Rufa and Microgyna species groups included F. microgyna, F. obscuripes, and F. ravida. The Sanguinea species group included F. puberula (a new record for British Columbia). Ants identified from the Lasius genus included L. crypticus.

Nomenclature followed Naumann et al. (1999), except for Myrmica crassirugus (Francoeur 2007) and Temnothorax (Mackay 2000). All species identifications were confirmed by Dr. Robert J. Higgins. The ant species and number of individuals per species were recorded for each pitfall trap.

\section{Analysis}

Four pitfall traps were either removed or destroyed by animals and were excluded from analysis. Ant species diversity was calculated with the use of the Hill diversity number (Ludwig and Reynolds 1988). Three two-way analyses of variance (ANOVAs) and post hoc Tukey tests were done to test the effects of elevation (lower and upper), and grazing (grazed, ungrazed) on the total number of ants captured, abundance of, species richness, and species diversity of ants. We also conducted two two-way ANOVAs and post hoc Tukey tests to test the effects of elevation and grazing on the number of Tapinoma sessile Say and Aphaenogaster occidentalis Emery because these two species were the most abundant. The factorial analyses were done with the use of Systat 13 (Systat 2009). Nonmetric multidimensional scaling (NMDS) was done with the use of the vegan package (Oksanen et al. 2010) in R (R Development Core Team 2008) to examine ant community composition. From random starting configurations a two-dimensional solution was sought with the use of a Bray-Curtis distance measure.

\section{RESULTS}

\section{Species Identified}

Ant species from eight genera were identified from the pitfall traps (Table 1). Most species were captured at both elevations; however, Camponotus vicinus Mayr, Solenopsis molesta Say,
Temnothorax rugatulus Emery, and Temnothorax nevadensis W. M. Wheeler were captured only in the lower grasslands; Myrmica fracticornis Forel and ants in the Formica sanguinea species group occurred only in the upper grasslands. Formica puberula Emery was a new record for British Columbia, Canada. Tapinoma sessile Say and Aphaenogaster occidentalis Emery were the most common species of ants captured in this study. Taken together these species represent $61.7 \%$ of all ants captured (T. sessile $=48.6 \%$, A. occidentalis $=13.1 \%)$.

\section{Elevation Effects}

The total number of ants captured was highest in upperelevation grasslands (Fig. 1a, Table 2), and so too was the number of ants captured of $T$. sessile $(6.21[ \pm 1.40 \mathrm{SE}]$ in upper elevation compared to $0.14[ \pm 0.07 \mathrm{SE}]$ in lower) and $A$. occidentalis (1.60 [ $\pm 0.28 \mathrm{SE}]$ in upper elevation compared to $0.12[ \pm 0.06 \mathrm{SE}]$ in lower). The mean species richness of ants was greater in upper-elevation grasslands (Fig. 1b; Table 2). Species diversity of ants did not differ between lower and upper grasslands (Fig. 1c; Table 2).

\section{Grazing Effects}

Grazing increased the total number of ants captured (Fig. 1a, Table 2), as well as increasing $T$. sessile $(\mathrm{F}=10.584$; $P=0.001)$ and $A$. occidentalis $(\mathrm{F}=3.75 ; P=0.05)$. There was no difference in species richness or diversity of ants between grazed and ungrazed areas (Table 2).

\section{Interacting Elevation and Grazing Effects}

Elevation and grazing had interacting effects on total numbers of ants captured, species richness, and diversity (Table 2). Upperelevation grazed sites had the highest total numbers of ants (as well as T. sessile and A. occidentalis); however, at lower elevation, ants were more numerous in exclosed areas than grazed areas (Fig. 1a). At lower elevation, species richness was higher in exclosures, but grazing had the opposite effect at upper elevation (Fig. 1b). Grazed lower-elevation sites had a lower species richness than grazed upper-elevation sites (Fig. 1b). Species diversity was higher in lower-elevation exclosure sites compared to lower-elevation grazed sites, but lower in upper-elevation exclosure sites compares to upper-elevation grazed sites (Fig. 1c).

\section{Nonmetric Multidimensional Scaling (NMDS)}

The NMDS found two convergent solutions after 14 tries and had a stress of 13.2 in two dimensions, the nonmetric fit between the observed dissimilarity and ordination distance was $R^{2}=0.982$. A three-dimensional solution had a lower stress, but we chose the two-dimensional solution because the stress value was acceptable (McCune and Grace 2002) and two dimensions was sufficient to express the variation within factors. The data separated out along the $x$ axis by elevation, with species and sites that occurred at lower elevation on the left and the species and sites that occurred at upper elevation on the right (Fig. 2).

\section{DISCUSSION}

In all four measured response variables (total ant abundance, $T$. sessile abundance, species richness, and Hill diversity) we found 

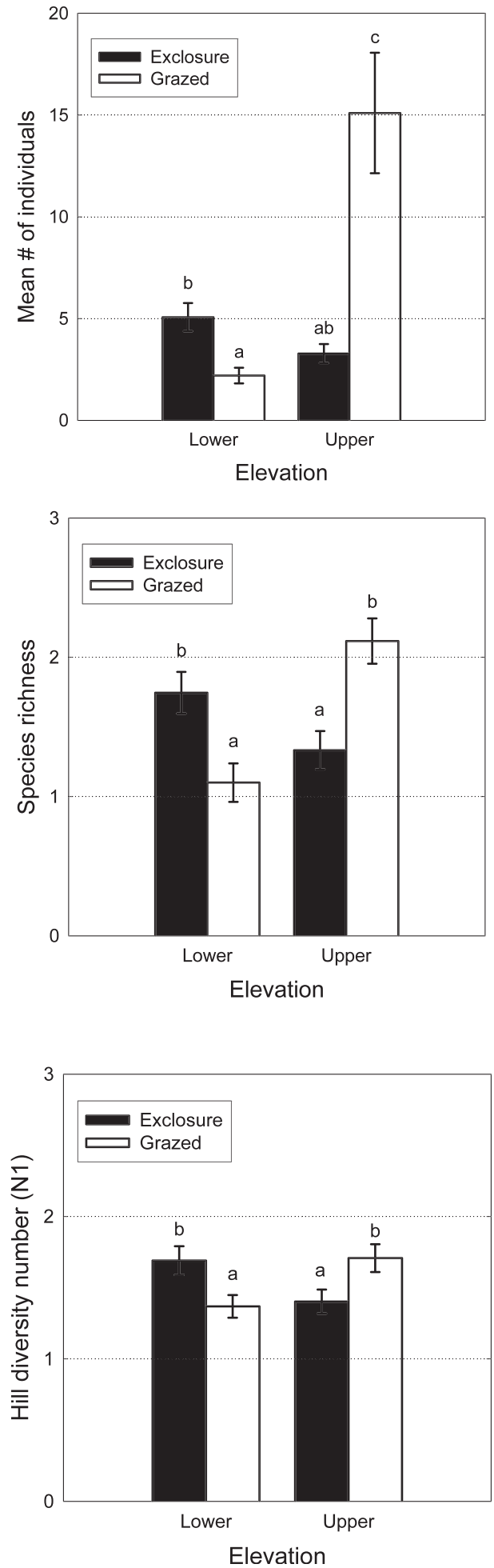

Figure 1. Mean $(+/-\mathrm{SE})$ relative total ant numbers captured (a), species richness (b), and species diversity (Hill diversity number N1) (c). Error bars indicate standard error. The letters above the error bars indicate significant differences among bars based on a post hoc Tukey test $(P<0.05)$.

interacting effects between elevation and grazing. We found that the number of ants captured increased in grazed sites at upper elevation (i.e., high productivity). However, ant numbers was reduced by grazing in lower-elevation sites. Because of the interaction effects, our results only show partial support for our two hypotheses.

Although pitfall traps are the most commonly used method for trapping ants in grasslands and sample surface-active ants effectively (Romero and Jaffe 1989; Hoffman 2010) they may be less effective for sampling ants that are active predominantly underground or on vegetation. Also, as previously stated, because some ants in a colony follow each other's trails (Hölldobler and Wilson 1990), the chance of catching an ant of a given species may increase with every ant of that species caught. Nevertheless, Romero and Jaffe (1989) recommend pitfall trapping for comparison between sites.

The total number of ants captured was generally greater in upper-elevation grasslands, as hypothesized; however, exclosures in upper grasslands had similar ant numbers as lowerelevation sites (both grazed and not grazed). Because elevation is a strong driver of site productivity in Lac du Bois Provincial Park (van Rieswick et al. 1966; Carlyle et al. 2011) we can interpret our findings with regards to differences in productivity. The NMS showed separation of ant species and study transects along the $x$ axis according to elevation. These results support the hypothesis that the number of ants in grasslands is limited by energy availability. Increased primary productivity could directly affect ant numbers because of an increase in available resources. An area with more resources can likely support greater numbers of individual ants. The results from this study are consistent with those found in a study done by Kaspari et al. (2000) that also evaluated the number of ants over a productivity gradient. Considering structural complexity may be useful in explaining these results. Generally, habitats with higher structural complexity support greater biodiversity because they provide more ecological niches; as such, the habitat requirements of more species can be met (Currie 1991). Bestelmeyer and Wiens (2001) found a relatively high ant richness and diversity in some Atriplex canescens shrub land, compared to short-grass steppe. In this study, lower elevation sites have grasses, bare ground and sage brush but high elevation sites have mostly rough fescue and other types of grass. It is possible that upper elevation, high productivity sites causes an increase in the abundance of only a few dominant species of ants, and that the lower levels of structural complexity is responsible for the decreased richness and diversity of ants captured there. In this case, the dominant ant species ( $T$. sessile and A. occidentalis) did have higher relative abundances in high productivity grasslands which provide some support for this idea. Additionally, the observation that C. vicinus occurred only in lower-elevation grasslands where the woody substrate they prefer for nesting is more available further supports this idea.

\section{Grazing Response}

The prediction that ants would be more abundant in ungrazed areas than in grazed areas was not supported; as a main effect, there was no difference in the relative abundance of ants between grazed and exclosed areas. Similarly, the species richness and species diversity of ants was not different between grazed and ungrazed areas. Predictions that the species richness and diversity of ants would be lower in grazed sites were originally based on the observation that generally heavy 
Table 2. Separate and interacting effects of elevation (lower and upper) and grazing (grazed and exclosures) on ant total number of ants captured, species richness, and Hill diversity. Bold numbers indicate significance at the $P<0.05$ level.

\begin{tabular}{|c|c|c|c|c|c|c|}
\hline & \multicolumn{2}{|c|}{ Total number of ants captured } & \multicolumn{2}{|c|}{ Species richness } & \multicolumn{2}{|c|}{ Hill diversity (N1) } \\
\hline & $\mathrm{F}$ & $P$ & $\mathrm{~F}$ & $P$ & $\mathrm{~F}$ & $P$ \\
\hline Elevation & 12.484 & $<0.001$ & 4.171 & 0.042 & 0.077 & 0.781 \\
\hline Grazing & 8.100 & 0.005 & 0.216 & 0.642 & 0.009 & 0.926 \\
\hline Elevation $\times$ grazing & 21.806 & $<0.001$ & 23.330 & $<0.001$ & 11.764 & 0.001 \\
\hline
\end{tabular}

grazing reduces ant density and diversity (Folgarait 1998; Hoffman 2010), but in this study the sites were moderately grazed, not heavily grazed. Still, the relative abundance of $T$. sessile was greater in grazed areas than exclosed areas. This indicates that grazing does effect the abundance of some species of ants and that grazing effects can act to increase ant numbers in some cases.

\section{Interacting Elevation and Grazing Responses}

Grazing and elevation (productivity) had significant interacting effects on the relative numbers of ants captured and species richness of ants. Areas with high productivity and grazing had a

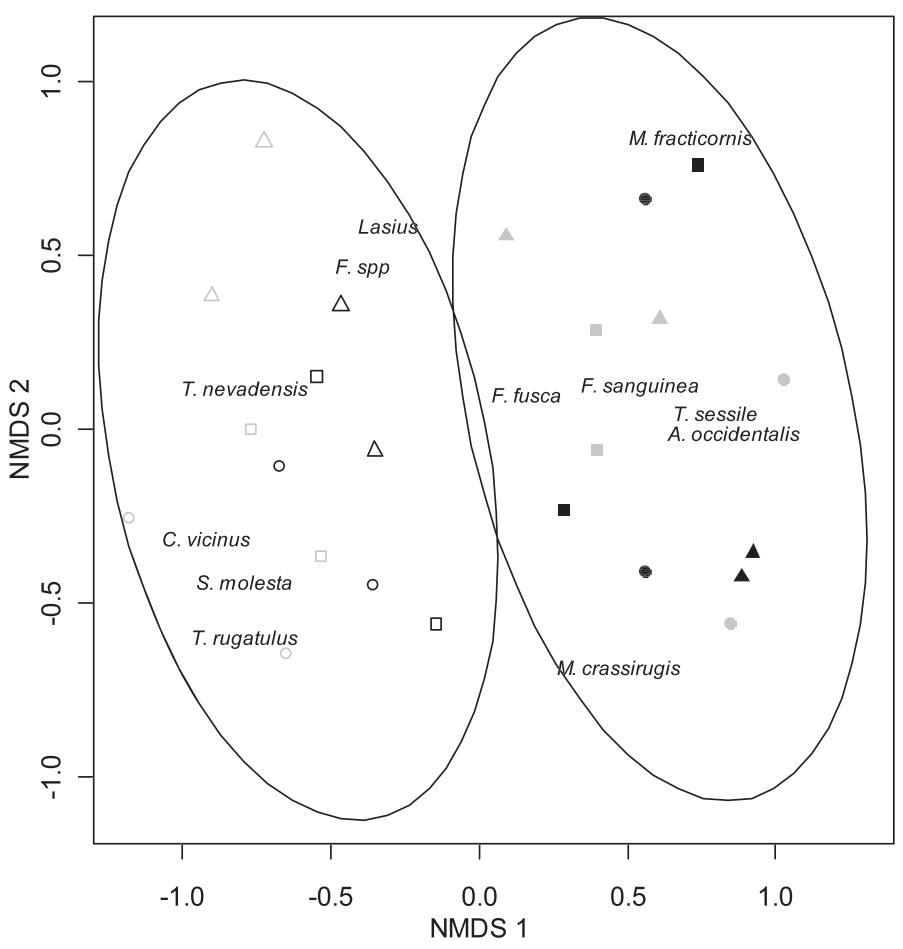

Figure 2. Multidimensional scaling ordination plot showing locations of transects and ant taxa. The ellipses (95\% confidence interval) indicate separation of the low- and high-elevation locations along NMDS 1, with the left representing low productivity grasslands and the right representing high productivity grasslands. Symbols are as follows: black $=$ grazed, gray $=$ ungrazed; triangle $=$ May, square $=$ July, circle = August; solid = high productivity, open=low productivity. The Fusca species group referred to as " $F$. fusca" included $F$. hewitti and F. subpolita. The Rufa and Microgyna species groups referred to as "F. spp." included F. microgyna, F. obscuripes, and F. ravida. The Sanguinea species group referred to as " $F$. Sanguinea" included F. puberula (a new record for British Columbia). Ants identified from the Lasius genus referred to as "Lasius" included L. crypticus. much higher number of ants than all other areas; however, of low productivity sites, exclosed areas had a higher relative number of ants than grazed areas. Structural complexity and resource availability were likely driving these patterns. The plant modification that takes place with grazing could be of varying importance depending on productivity of the site, because both the quantity and the type of vegetation changes at different elevations. These differences may be affecting both competitors and predators of ants. In a study on seed-eating rodents and ants, it was found that changes in the population of each were reciprocal as a result of competition for resources (Brown et al. 1979). It is possible that seed-eating rodents and other granivores such as birds find the high productivity, ungrazed grasslands in this study to be a more suitable habitat than the high productivity, grazed grasslands because ungrazed vegetation provides better cover from predators (Carlyle et al. 2010). The higher competition in ungrazed areas at high productivity would likely reduce ant abundance there. In a similar way, the ungrazed high productivity grasslands may provide a better habitat for predators of ants such as spiders and birds, which would also act to reduce ant abundance. At low productivity, a different pattern is seen, as exclosed areas had a higher relative abundance than grazed areas. The high abundance of big sagebrush at lower sites could be providing the cover and habitat needed for predators and competitor species to ants, allowing resource availability to be the prevailing driving factor at those sites. Species richness of ants was also affected by the interacting effects of productivity and grazing. The highest species richness occurred in exclosed ungrazed sites, and the trend for species diversity was similar but was not significant. This is likely due to higher structural complexity owing to the presence of big sagebrush and lack of grazing.

\section{Species Descriptions}

Two species, $T$. sessile and A. occidentalis, represented more than $60 \%$ of all ants captured. Tapinoma sessile was the only species caught from the subfamily Dolichoderinae during this study, and was captured at both low and high productivity sites. This species can be lestobiotic (meaning that it nests in the walls of other species' nests, steals food and resources from the host nest, and preys upon host workers and brood), but can also be independent, forming nests in soil or under rocks, wood, or dung. This small ant typically has colonies with thousands of individuals and feeds on fruit juices, nectars, flesh of other organisms and sometimes tends aphids or other honeydew secretors (Smith 1928; Naumann et al. 1999; Heron 2005). Aphaenogaster occidentalis is a species that nests in both extremely covered and open areas and usually has hundreds of individuals in each colony (Naumann et al. 
1999; Heron 2005). This slow-moving ant was captured at both low and high productivity sites and was relatively numerous in this study, as well as in a grassland study done by Heron (2005).

\section{MANAGEMENT IMPLICATIONS}

Ants perform many different ecosystem functions and therefore have extensive impacts on their environment. Although grassland management is typically concerned with vegetation and mammals, consideration of invertebrates such as ants is important for maintaining biodiversity and ecosystem function. The results of this study are useful for informing grazing and biodiversity management of grasslands. This study suggests that when designing grazing regimes ant diversity could be maximized to contribute to overall biodiversity by maintaining and adding to exclosed areas, or reducing grazing intensity, at low productivity levels. This would be most important early in the growing season; avoiding grazing in low productivity areas altogether until later in the season when impacts on species richness would be less severe would also help to increase biodiversity.

\section{ACKNOWLEDGMENTS}

We thank Jessica Gossling and Anna-Maria Pellet for help collecting pitfalls in the field. Dr. Rob Higgins verified identification of ant taxa. We thank Agriculture and Agri-Foods Canada, Kamloops Range Research branch for allowing use of cattle exclosures and the British Columbia Ministry of Environment for allowing access to Lac du Bois Provincial Park. This work was funded by a Natural Sciences and Engineering Research Council (NSERC) Discovery Grant to L.H.F.

\section{LITERATURE CITED}

Abensperg-Traun, M., G. T. Smith, G. W. Arnold, and D. E. Steven. 1996. The effects of habitat fragmentation and livestock grazing on animal communities in remnants of gimlet Eucalyptus salubris woodland in the Western Australian wheatbelt. I. Artropids. Journal of Applied Ecology 33:1281-1301.

Andersen, A. N. 1995. A classification of Australian ant communities, based on functional groups which parallel plant life-forms in relation to stress and disturbance. Journal of Biogeography 22:15-29.

Andersen, A. N. 1997. Functional groups and patterns of organization in North American ant communities: a comparison with Australia. Journal of Biogeography 24:433-460.

Andersen, A. N., And J. D. Majer. 2004. Ants show the way down under: invertebrates as bioindicators in land management. Frontiers in Ecology and the Environment 2:291-298.

BASSET, E. R. L. 2009. The effects of grazing and site productivity on carabid beetles (Coleoptera: Carabidae) in a semi-arid grassland [master of science thesis]. Kamloops, British Columbia, Canada: Thompson Rivers University.

Bates, J. D., R. F. Miller, and T. J. Svejcar. 2000. Understory dynamics in cut and uncut western juniper woodlands. Journal of Range Management 53:119-126.

Bestelmeyer, B. T., and J. A. Wiens. 1996. The effects of land use on the structure of ground-foraging ant communities in the Argentine Chaco. Ecological Applications 6:1225-1240.

BestelmeYer, B. T., AND J. A. Wiens. 2001. Ant biodiversity in semiarid landscape mosaics: the consequences of grazing vs. natural heterogeneity. Ecological Applications 11:1123-1140.
BRoSE, U. 2003. Bottom-up control of Carabid beetle communities in early successional wetlands: mediated by vegetation structure or plant diversity? Oecologia 135:407-413.

Brown, J. H., and D. W. Davidson. 1977. Competition between seed-eating rodents and ants in desert ecosystems. Science 196:880-882.

Brown, J. H., D. W. Davidson, and 0. J. Reichman. 1979. An experimental study of competition between seed-eating desert rodents and ants. American Journal of Zoology 19:1129-1143.

Bull, E. L., T. R. Torgerson, A. K. Blumton, C. M. McKenzie, and D. S. Wyland. 1995. Treatment of an old-growth stand and its effects on birds, ants, and large woody debris: a case study. Portland, OR, USA: USDA Forest Service Pacific Northwest Research Station. Gen. Tech. Rep. PNW-GTR-353. 12 p.

Carlyle, C. N., L. H. Fraser, C. M. Haddow, B. A. Bings, and W. Harrower. 2010. The use of digital photos to assess visual cover for wildlife in rangelands. Journal of Environmental Management 91:1366-1370.

Carlyle, C. N., L. H. Fraser, and R. Turington. 2011. Tracking soil temperature and moisture in a multi-factor climate experiment in temperate grassland: do climate manipulation methods produce their intended effects? Ecosystems 14:489-502.

Connell, J., AND E. ORIAs. 1964. The ecological regulation of species diversity. American Naturalist 98:399-414.

CuRRIE, D. J. 1991. Energy and large-scale patterns of animal- and plant-species richness. American Naturalist 137:27-49.

Environment Canada. 2009. National Climate Data and Information archive. Available at: http://climate.weatheroffice.ec.gc.ca/climate_normals/index_e.html. Accessed 6 October 2009

Folgarait, P. J. 1998. Ant biodiversity and its relationship to ecosystem functioning: a review. Biodiversity and Conservation 7:1221-1244.

Francoeur, A. 2007. The Myrmica punctiventris and M. crassirugis species groups in the Nearctic region. Memoirs of the American Entomological Institute 80:153-185.

Grandchamp, A. C., A. Bergamini, S. Stofer, J. Niemela, P. Duelli, and C. Scheidegger. 2005. The influence of grassland management on ground beetles (Carabidae, Coleoptera) in Swiss montane meadows. Agriculture, Ecosystems and Environment 110:307-317.

Havstad, K. M. 2008. Mongolia's rangelands: is livestock production the key to the future? Frontiers in Ecology and the Environment 6:385-391.

Heron, J. 2005. Ants of the south Okanagan grasslands, British Columbia. Arthropods of Canadian Grasslands 11:17-22.

Higgins, R. J., AND B. S. Lindgren. 2006. The fine scale physical attributes of coarse woody debris and effects of surrounding stand structure on its utilization by ants (Hymenoptera: Formicidae) in British Columbia. In: Insect biodiversity and dead wood: Proceedings of a symposium for the 22nd International Congress of Entomology. Asheville, NC, USA: USDA Forest Service Southern Research Station. Gen. Tech. Rep. SRS-93. p. 67-74.

Hoffmann, D. B. 2010. Using ants for rangeland monitoring: global patterns in the responses of ant communities to grazing. Ecological Indicators 10: $105-111$.

Hölldobler, B., and E. O. Wilson. 1990. The ants. Cambridge, MA, USA: The Belknap Press of Harvard University Press.

Hutchinson, G. E. 1959. Homage to Santa Rosalia, or why are there so many kinds of animals? American Naturalist 93:145-159.

KaSPARI, M., S. O'DonnelL, And J. R. KerCher. 2000. Energy, density, and constraints to species richness: ant assemblages along a productivity gradient. American Naturalist 155:280-293.

Ludwig, J. A., And Reynolds, J. F. 1988. Statistical Ecology: A Primer on Methods and Computing. New York, NY, USA: John Wiley \& Sons.

MaCKAY, W. P. 2000. A review of the New World ants of the subgenus Myrafant, (genus Leprothorax) (Hymenoptera: Formicidae). Sociobiology 36:265-444.

Majer, J. D., AND G. Beeston. 1996. Biodiversity integrity index: an illustration using ants in Western Australia. Conservation Biology 10:65-74.

McCune, B., and J. B. Grace. Analysis of ecological communities. Gleneden Beach, OR, USA: MjM Software Design.

Naumann, K., W. B. Preston, and G. L. Ayre. 1999. An annotated checklist of the ants (Hymenoptera: Formicidae) of British Columbia. Journal of the Entomological Society of British Columbia 96:29-68. 
Noyce, K. V., P. B. Kannowski, and M. R. Riggs. 1997. Black bears as anteaters: seasonal associations between bear myrmicophagy and ant ecology in north central Minnesota. Canadian Journal of Zoology 75:1671-1686.

Oksanen, J., F. G. Blanchet, P. Kindt, P. Legendre, R. B. O’Hara, G. L. Simpson, P. Solymos, M. H. H. Stevens, and H. Wagner. 2010. vegan: Community Ecology Package. $\mathrm{R}$ package version 1.17-3.

R Development Core Team. 2008. R: a language and environment for statistical computing. Vienna, Austria: R Foundation for Statistical Computing. Available at: http://www.R-project.org.

RAINE, R. M., AND J. L. KANSAS. 1990. Black bear seasonal food habits and distribution by elevation in Banff national park, Alberta. In: L. M. Darling and W. R. Archibald [EDS.] Proceeding for the Eighth International Conference of Bear Research and Management. Victoria, BC, Canada: International Association for Bear Research and Management. p. 297-304.
Romero, H., and K. Jaffe. 1989. A comparison of methods for sampling ants (Hymenoptera, Formicidae) in savannas. Biotropica 21:348-352.

Sмıтн, M. R. 1928. The biology of Tapinoma sessile Say, an important-house infesting ant. Annals of the Entomological Society of America 21:307-330.

SYSTAT SoftwARE, Inc. 2009. SYSTAT 13 Statistics. Chicago, IL, USA: SYSTAT Software, Inc.

Torgerson, T. R., and E. V. Bull. 1995. Down logs as habitat for forest dwelling ants-the primary prey of pileated woodpeckers in northeastern Oregon. Northwest Science 69:294-303.

van Ryswyk, A. L., A. McLean, and L. S. Marchand. 1966. The climate, native vegetation, and soils of some grasslands at different elevations in British Columbia. Canadian Journal of Plant Science 46:35-50.

Whitford, W. G., D. Schaefer, And W. Wisdom. 1986. Soil movement by desert ants. Southwest Naturalist 31:273-274 